\title{
The relationship between affective disorders and hormonal and metabolic parameters in women with polycystic ovary syndrome
}

\author{
Polikistik over sendromlu kadınlarda afektif bozukluklar ile hormonal ve metabolik \\ parametreler arasındaki ilişki
}

\author{
Nilgün Güdücü ${ }^{1}$, Uzay Görmüş ${ }^{2}$ Özge Başak Kayan ${ }^{1}$, Zehra Neşe Kavak³ ${ }^{3}$ ilkkan Dünder ${ }^{1}$
}

\begin{abstract}
Objective: To understand the relationship among affective disorders and hormonal and biochemical parameters in women with polycystic ovary syndrome (PCOS).

Methods: Women with PCOS $(n=15)$ were compared to body mass index and age matched control group $(n=19)$. Beck Depression Inventory and Stait Trait Anxiety Inventory were used to assess the presence of depression and anxiety symptoms.

Results: Depression and anxiety scores of women with PCOS correlated with free testosterone levels. Their anxiety scores correlated with HDL and lipoprotein-a (Lp-a), an independent marker for increased cardiovascular disease. In the control group anxiety score correlated with interleukin-1 $\beta$.

Conclusion: There was a relationship between increased androgens and affective disorders in women with PCOS. The correlation between Lp-a and anxiety scores may be the link between affective disorders and cardiovascular diseases. A different mechanism may play role in the pathophysiology of affective disorders in women with PCOS. J Clin Exp Invest 2013; 4 (1): 13-19
\end{abstract}

Key words: Polycystic ovary syndrome, testosterone, depression, anxiety

\section{INTRODUCTION}

Polycystic ovary syndrome (PCOS) is a common endocrinological disorder, where the patients present with chronic oligo/anovulation, clinical and/ or biochemical hyperandrogenism and polycystic ovaries on ultrasound. ${ }^{1}$ In women with PCOS hyperandrogenism, insulin resistance (IR) and obesity produce a vicious cycle and lead to other metabolic problems. Recently, a chronic low-grade

\section{ÖZET}

Amaç: Polikistik over sendromlu (PKOS) hastalarda afektif bozukluklar ile hormonal ve biyokimyasal parametreler arasındaki ilişkiyi anlamak.

Yöntemler: PKOS tanısı almış 15 hasta, yaş ve vücut kitle endeksi benzer olan kontrol grubuyla $(n=19)$ karşılaştırıldı. Beck Depresyon Ölçeği ve Durumluk-Sürekli Anksiyete Ölçeği kullanılarak anksiyete ve depresyon semptomları sorgulandı.

Bulgular: Polikistik over sendromlu hastaların depresyon ve anksiyete skorları serbest testosterone seviyeleri ile korele idi. Anksiyete skorları HDL ve kardiyovasküler hastalıklar için bağımsız bir risk faktörü olarak kabul edilen lipoprotein-a ile koreleydi. Kontrol grubunda anksiyete skorları interlökin 1 beta ile koreleydi.

Sonuç: Polikistik over sendromlu hastalarda androjenler ve afektif bozukluklar arasında bağlantı vardır. Lipoprotein-a ve anksiyete skorları arasındaki korelasyon afektif bozukluklar ve kardiyovasküler hastalıklar arasındaki bağ olabilir. Polikistik over sendromlu kadınlarda afektif bozuklukların patofizylojisinde farklı bir mekanizma rol oynayabilir.

Anahtar kelimeler: Polikistik over sendromu, testosterone, anksiyete, depresyon

inflammatory state is being proposed as the underlying mechanism of atherosclerosis and affective disorders such as depression and anxiety. ${ }^{2,3}$ An increased prevalence of depression was also reported in patients suffering from metabolic syndrome (MS). ${ }^{4,5}$ Levels of inflammatory biomarkers were higher in MS patients with depression when compared to those without MS. ${ }^{5}$ Women with PCOS have an increased prevalence of MS and its components. A recent study analyzing depression and

\footnotetext{
${ }^{1}$ Istanbul Bilim University, Avrupa Hospital, Department of Obstetrics and Gynecology, Istanbul, Turkey 2 istanbul Bilim University, Department of Biochemistry, Istanbul, Turkey

${ }^{3}$ Marmara University, Department of Obstetrics and Gynecology, Istanbul, Turkey
}

Correspondence: Nilgün Güdücü,

İstanbul Bilim Unıversity, Avrupa Hospital, Dept. Obstetrics\&Gynecology, İstanbul, Turkey Email: nilgun.kutay@gmail.com Received: 15.11.2012, Accepted: 07.01.2013

Copyright (C) JCEI / Journal of Clinical and Experimental Investigations 2013, All rights reserved 
anxiety in PCOS patients detected a correlation between cardiovascular risk factors and depression scores. ${ }^{6}$ Women with PCOS has augmented levels of androgens. The embarrassment caused by clinical manifestations of hyperandrogenism (alopecia, hirsutism, acne), obesity and infertility may decrease self-esteem and may increase body dissatisfaction in women with PCOS. In addition, future health consequences related to PCOS may increase their anxiety. These features may also increase the probability of weight gain by inducing social isolation and creating further opportunity to eat. The metabolic components of affective disorders are not clear. We conducted this study in effort to search the relationship among cardiovascular disease risk markers, hormonal parameters and affective disorders in PCOS patients.

\section{METHODS}

This study was performed by recruiting patients from the Obstetrics and Gynecology policlinic of İstanbul Bilim University Avrupa Hospital. The study protocol was approved by the Institutional Review Board of İstanbul Bilim University. The study protocol was in confirmation with the ethical guidelines of the Declaration of Helsinki. Women with PCOS who gave blood for tests in the last 3 months were invited to participate this study. Diagnosis of PCOS was established according to 2003 Rotterdam ESHRE/ASRM PCOS Consensus Workshop Group Criteria, ${ }^{7}$ when at least two of the following criteria were present: oligo/amenorrhea (cycles lasting longer than 35 days), clinical and/or biochemical hyperandrogenism and PCO (presence of an ovary with 12 or more follicles measuring $2-9 \mathrm{~mm}$ in diameter on ultrasonography). All of the subjects in the control group were age and body mass index (BMI) matched, most of them were students of medicine and hospital staff, they had a normal pelvic ultrasound, regular periods and no clinical and biochemical hyperandrogenism. Patients with systemic diseases as diabetes mellitus, cardiovascular diseases, hypertension, thyroid diseases, chronic renal failure, malignancy, Cushing syndrome, congenital adrenal hyperplasia, hyperprolactinemia and gastrointestinal malabsorptive diseases were excluded. None of the patients were on any medications for at least 3 months before the study including oral contraceptives, glucocorticoids, lipid-lowering, antiobesity, antidiabetes, antiandrogenic, antihypertensive or ovulation-inducing agents. We obtained written informed consent from all of the participants.

All of the patients underwent a physical examination and appropriate laboratory tests were performed. BMI was calculated as body weight in kilograms divided by height in metre squared $(\mathrm{kg} /$ $\mathrm{m}^{2}$ ). We measured weight, height and waist and hip circumferences. Waist circumference (WC) was obtained as the smallest circumference at the level of umbilicus. Hip circumference ( $\mathrm{HC}$ ) was obtained as the widest circumference at the level of the buttocks. Serum samples were obtained from all women in the early follicular phase after an overnight of fasting, during the 3rd-4th days of the cycle. Levels of fasting plasma glucose, insulin, total cholesterol, high-density lipoprotein (HDL), low density lipoprotein (LDL), triglycerides (TG), Luteinizing Hormone $(\mathrm{LH})$, Follicle Stimulating Hormone ( $\mathrm{FSH})$, prolactin, Thyroid Stimulating Hormone (TSH), C-reactive protein (CRP), dehydroepiandrosterone sulfate (DHEAS), free testosterone, cortisol, free T4, 17$\mathrm{OH}$ progesterone, estradiol (E2), sex-hormone binding globulin (SHBG) and lipoprotein-a (Lp-a) were measured. All of the parameters were studied readily except interleukin-6 (IL-6) and interleukin-1 $\beta$ (IL-1 $\beta$ ). Centrifuged blood was stored at $-80^{\circ} \mathrm{C}$ and levels of IL- 6 and IL-1 $\beta$ were studied later.

Free androgen index (FAI) was calculated with the formula $\mathrm{FAl}=$ total testosterone $(\mathrm{nmol} / \mathrm{l}) \times 100 /$ SHBG (nmol/L), FAl levels $\geq 5$ were indicative of PCOS.8 Insulin resistance was calculated by homeostasis model assessment (HOMA) index with the formula: HOMA-IR= fasting insulin $(\mathrm{mU} / \mathrm{ml}) \mathrm{x}$ fasting plasma glucose $(\mathrm{mg} / \mathrm{dl}) / 405$. HOMA-IR levels less than $2.75 \mathrm{mg} / \mathrm{dl}$ were considered as normal.

To assess depressive symptoms we used a Turkish version of 21 item Beck Depression Inventory (BDI), a score $\geq 17$ was considered as the presence of severe depressive symptoms that require treatment, a score $<11$ was considered as the absence of depressive symptoms and a score of 1116 was considered as the presence of mild-to-moderate depressive symptoms. To measure the level of anxiety among patients we used a Turkish version of State-Trait Anxiety Inventory (STAI) which is composed of two separate scales, STAI-State (acute) and STAI-Trait (long-standing). Each scale consisted of 20 statements that addressed the anxiety level of the participant. A sum of scores $\geq 42$ was considered as the presence of severe anxiety, a score of 37-41 was considered as the presence of mild-moderate anxiety and a score $<36$ was considered as the absence of anxiety.

\section{Statistical analysis}

Statistical analyses were performed using the NCSS (Number Cruncher Statistical System) 2007\&PASS (Power Analysis and Sample Size) 2008 Statistical 
Software (Utah). Data showing normal distribution of parameters were compared with Student's t-test, data showing non-normal distribution of parameters were compared with Mann Whitney $U$ test, qualitative data were compared with Chi-square test, correlation of BDI, STAI-S and STAI-T with other parameters were measured with Spearman's and Pearson correlation analysis. At a confidence interval of $95 \%$ p-values $<0.05$ were considered statistically significant.

\section{RESULTS}

Mean age of PCOS patients was $25.4 \pm 5.3$ years and control group was $27.2 \pm 5.5$ years $(p=0.346)$, mean BMI of PCOS patients was $24.0 \pm 5.4 \mathrm{~kg} / \mathrm{m}^{2}$ and control group was $24.09 \pm 6.68 \mathrm{~kg} / \mathrm{m} 2$ ( $p=0.985)$, mean WHR of PCOS patients was $0.82 \pm 0.07$ and control group was $0.83 \pm 0.06(p=0.706)$, mean Systolic BP of PCOS patients was $97.5 \pm 12.1 \mathrm{mmHg}$ and control group was $101.5 \pm 10.6 \mathrm{mmHg}(p=0.386)$, mean Diastolic BP of PCOS patients was $61.6 \pm 7.1 \mathrm{mHg}$ and control group was $66.9 \pm 8.55 \mathrm{mmHg}(p=0.111)$. Results of BDI, STAI-S and STAI-T were presented in Table 1. Participants in the control group had higher anxiety scores when compared to PCOS group $(p<0.05)$. Biochemical and hormonal parameters of women with PCOS and the control group were compared in Table 2. As expected women with PCOS had statistically significantly higher free testosterone, free androgen index (FAI), $\mathrm{LH}$ and lower FSH when compared to the control group $(p<0.05)$.

Correlation of BDI, STAI-S and STAI-T scores of PCOS patients with hormonal, biochemical and anthropometric parameters were given in Table 3. $\mathrm{BDI}$ scores were correlated with free testosterone and FAI positively $(r=0.806, p=0.001$ and $r=0.551$, $p=0.041$ respectively) and with HDL negatively ( $r=-$ 0.666 and $p=0.007$ ). STAI-S scores correlated positively with free testosterone $(r=0.553$ and $p=0.032)$ and negatively with $\mathrm{HDL}$ and TSH $(\mathrm{r}=-0.513, \mathrm{p}=0.05$ and $r=-0.550, p=0.034$ respectively). STAI-T scores correlated positively with free testosterone and lipoprotein-a $(r=0.640, p=0.01$ and $r=0.566, p=0.035)$.

Correlation of BDI, STAI-S and STAI-T scores of the control group with hormonal, biochemical and anthropometric parameters were given in Table 4. Only STAI-T score correlated positively with IL-1 $\beta$ $(r=0.468$ and $p=0.043)$.

Table 1. Comparation of Beck Depression Inventory (BDI), State Trait Anxiety Inventory-State (STAI-S) and -Trait (STAI-T) points of PCOS and control groups (mean \pm standard deviation)

\begin{tabular}{|c|c|c|c|c|}
\hline & & $\begin{array}{l}\text { PCOS Group } \\
(n=15)\end{array}$ & $\begin{array}{l}\text { Control Group } \\
(\mathrm{n}=19)\end{array}$ & $p$-value \\
\hline BDI & & $9.4 \pm 7.9$ (8) & $12.7 \pm 7.2(11)$ & a 0.321 \\
\hline STAI-S & & $31.8 \pm 10.7$ & $40.7 \pm 10.3$ & $0.021^{*}$ \\
\hline \multirow[t]{2}{*}{ STAI-T } & & $40.1 \pm 8.5$ & $42.6 \pm 7.7$ & 0.364 \\
\hline & & $\mathrm{n}(\%)$ & n (\%) & ${ }^{\mathrm{b} p}$ \\
\hline \multirow[t]{3}{*}{ BDI } & Normal & $9(60)$ & $9(47.4)$ & \\
\hline & Minor & $4(26.7)$ & $4(21.1)$ & 0.461 \\
\hline & Depressive & $2(13.3)$ & $6(31.6)$ & \\
\hline \multirow[t]{2}{*}{ STAI-S } & Normal & $12(80)$ & 7 (38.9) & 0.043 \\
\hline & Anxious & $3(20)$ & $11(61.1)$ & * \\
\hline \multirow[t]{3}{*}{ STAI-T } & Normal & $6(40)$ & 4 (21.1) & \\
\hline & Minor Anxiety & $4(26.7)$ & $5(26.3)$ & 0.421 \\
\hline & Anxious & $5(33.3)$ & $10(52.6)$ & \\
\hline
\end{tabular}

a Mann Whitney U Test, ${ }^{b}$ Chi-square test, ${ }^{*} p<0.05$ 
Table 2. Biochemical and hormonal parameters of the control and PCOS group [Mean \pm Standard Deviation (Median)]

\begin{tabular}{|c|c|c|c|}
\hline & $\begin{array}{l}\text { PCOS } \\
(n=15)\end{array}$ & $\begin{array}{l}\text { Controls } \\
(n=19)\end{array}$ & $\mathrm{p}$ \\
\hline Fasting blood glucose (mg/dl) & $91.47 \pm 5.5$ & $89.6 \pm 6.1$ & 0.370 \\
\hline alL-6 (ng/dl) & $13.3 \pm 7.4(10.4)$ & $14.1 \pm 4.9(12.6)$ & 0.066 \\
\hline IL-1 $\beta$ (ng/dl) & $9.1 \pm 1.8$ & $9.4 \pm 1.8$ & 0.691 \\
\hline E2 (pg/ml) & $34.6 \pm 7.8$ & $35.7 \pm 11.6$ & 0.751 \\
\hline aTriglyceride(mg/dl) & $63.8 \pm 32(54)$ & $67.2 \pm 26.4(68)$ & 0.455 \\
\hline $\mathrm{HDL}(\mathrm{mg} / \mathrm{dl})$ & $54.2 \pm 14.9$ & $54 \pm 12.4$ & 0.957 \\
\hline LDL (mg/dl) & $101.3 \pm 29.3$ & $99.8 \pm 32$ & 0.886 \\
\hline aD-HEAS (ug/dl) & $289.2 \pm 101.6(296.2)$ & $262 \pm 156(209)$ & 0.157 \\
\hline aFree Testosterone (ng/dl) & $0.67 \pm 0.3(0.6)$ & $0.47 \pm 0.3(0.4)$ & $0.023^{*}$ \\
\hline Insulin (uU/ml) & $8.9 \pm 4.9$ & $10 \pm 4.7$ & 0.488 \\
\hline aLipoprotein-a (mg/dl) & $21.9 \pm 22.7(10.7)$ & $28.5 \pm 39.9(9.4)$ & 0.742 \\
\hline${ }^{\mathrm{a}} \mathrm{CRP}(\mathrm{mg} / \mathrm{l})$ & $1.6 \pm 3.6(0.16)$ & $0.99 \pm 1.2(0.6)$ & 0.199 \\
\hline $\mathrm{FSH}(\mathrm{mlU} / \mathrm{ml})$ & $5.3 \pm 1.6$ & $6.9 \pm 2.3$ & $0.029^{*}$ \\
\hline aLH (mlU/ml) & $8.6 \pm 3.6(6.8)$ & $5.7 \pm 2.3(4.7)$ & $0.010^{*}$ \\
\hline aTSH (ulU/ml) & $2 \pm 0,9(2)$ & $2.4 \pm 1.1(2)$ & 0.543 \\
\hline aHOMA-IR & $2.4 \pm 1.52(1.8)$ & $2.3 \pm 1.1(2)$ & 0.903 \\
\hline aSHBG (nmol/l) & $48.9 \pm 27(36.9)$ & $50.8 \pm 29(38.7)$ & 0.689 \\
\hline aFAl & $3.7 \pm 1.9(3.4)$ & $2.6 \pm 2(1.9)$ & $0.042^{*}$ \\
\hline
\end{tabular}

a Mann Whitney U Test, ${ }^{*} p<0.05$

Table 3. Correlation among anthropometric, hormonal and biochemical parameters and Beck Depression Inventory (BDI), State Trait Anxiety Inventory-State (STAI-S) and -Trait (STAI-T) scores in PCOS group

\begin{tabular}{|c|c|c|c|c|c|c|}
\hline \multirow[t]{2}{*}{ PCOS Group } & \multicolumn{2}{|l|}{$\mathrm{BDI}$} & \multicolumn{2}{|l|}{ STAI-S } & \multicolumn{2}{|l|}{ STAI-T } \\
\hline & $a_{r}$ & $\mathrm{p}$ & $r$ & $\mathrm{p}$ & $r$ & $\mathrm{p}$ \\
\hline Age & -0.151 & 0.590 & 0.078 & 0.781 & 0.006 & 0.984 \\
\hline Weight & 0.330 & 0.230 & -0.027 & 0.925 & 0.384 & 0.157 \\
\hline Height & 0.026 & 0.926 & 0.131 & 0.643 & 0.136 & 0.628 \\
\hline BMI & 0.333 & 0.225 & -0.060 & 0.831 & 0.344 & 0.210 \\
\hline WHR & 0.450 & 0.093 & $0.120^{\mathrm{a}}$ & 0.670 & $0.258^{a}$ & 0.353 \\
\hline Fasting Blood Glucose & -0.022 & 0.937 & -0.184 & 0.511 & -0.069 & 0.808 \\
\hline IL-6 & 0.147 & 0.601 & 0.166 & 0.553 & -0.083 & 0.768 \\
\hline IL-1 $\beta$ & -0.036 & 0.899 & 0.030 & 0.915 & -0.073 & 0.796 \\
\hline E2 & -0.127 & 0.651 & 0.017 & 0.953 & -0.149 & 0.595 \\
\hline TGC & 0.438 & 0.102 & 0.014 & 0.960 & 0.404 & 0.135 \\
\hline HDL & -0.666 & $0.007^{* *}$ & -0.513 & $0.050^{*}$ & -0.461 & 0.084 \\
\hline LDL & 0.438 & 0.103 & 0.077 & 0.786 & 0.429 & 0.111 \\
\hline D-HEAS & 0.382 & 0.160 & 0.430 & 0.110 & 0.472 & 0.076 \\
\hline F.Testosterone & 0.806 & $0.001^{* *}$ & 0.553 & $0.032^{*}$ & 0.640 & $0.010^{*}$ \\
\hline Insulin & 0.054 & 0.849 & 0.080 & 0.778 & 0.067 & 0.811 \\
\hline Lipoprotein-a & 0.465 & 0.094 & 0.258 & $0.374^{a}$ & $0.566^{a}$ & $0.035^{*}$ \\
\hline CRP & 0.194 & 0.489 & $-0.074^{a}$ & 0.792 & $-0.213^{a}$ & 0.446 \\
\hline $\mathrm{FSH}$ & -0.106 & 0.707 & -0.278 & 0.315 & -0.089 & 0.752 \\
\hline LH & -0.109 & 0.698 & -0.055 & 0.847 & 0.076 & 0.788 \\
\hline TSH & -0.209 & 0.295 & -0.550 & $0.034^{*}$ & -0.456 & 0.087 \\
\hline HOMA-IR & 0.146 & 0.603 & $-0.444^{a}$ & 0.877 & $-0.077^{a}$ & 0.784 \\
\hline SHBG & -0.406 & 0.150 & $-0.238^{a}$ & 0.413 & $-0.177^{a}$ & 0.545 \\
\hline FAl & 0.551 & $0.041^{*}$ & $0.297^{\mathrm{a}}$ & 0.302 & $0.361^{\mathrm{a}}$ & 0.205 \\
\hline Systolic BP & -0.306 & 0.334 & -0.320 & 0.311 & 0.230 & 0.472 \\
\hline Diastolic BP & -0.184 & 0.567 & -0.307 & 0.332 & 0.158 & 0.624 \\
\hline
\end{tabular}

$\mathrm{r}=$ Spearman's rho, ${ }^{\mathrm{a}} \mathrm{r}=$ Pearson Correlation, ${ }^{*} \mathrm{p}<0.05,{ }^{* *} \mathrm{p}<0.01$ 
Table 4. Correlation among anthropometric, hormonal and biochemical parameters and Beck Depression Inventory (BDI), State Trait Anxiety Inventory-State (STAI-S) and -Trait (STAI-T) scores in the control group

\begin{tabular}{|c|c|c|c|c|c|c|}
\hline \multirow[t]{2}{*}{ Control Group } & \multicolumn{2}{|l|}{$\mathrm{BDI}$} & \multicolumn{2}{|l|}{ STAI-S } & \multicolumn{2}{|l|}{ STAI-T } \\
\hline & $a_{r}$ & $\mathrm{p}$ & $r$ & $\mathrm{p}$ & $r$ & $\mathrm{p}$ \\
\hline Age & -0.450 & 0.053 & -0.183 & 0.468 & 0.005 & 0.984 \\
\hline Weight & -0.033 & 0.895 & -0.323 & 0.191 & -0.215 & 0.377 \\
\hline Height & -0.019 & 0.938 & 0.410 & 0.091 & -0.138 & 0.573 \\
\hline BMI & 0.026 & 0.915 & -0.453 & 0.059 & -0.223 & 0.359 \\
\hline WHR & -0.391 & 0.097 & $-0.158^{a}$ & $0.532^{\mathrm{a}}$ & $-0.015^{a}$ & 0.953 \\
\hline Fasting Blood Glucose & 0.175 & 0.473 & -0.067 & 0.791 & -0.051 & 0.837 \\
\hline IL-6 & 0.089 & 0.718 & 0.174 & 0.490 & 0.159 & 0.517 \\
\hline IL-1 $\beta$ & 0.244 & 0.313 & 0.459 & 0.055 & 0.468 & $0.043^{*}$ \\
\hline E2 & -0.022 & 0.929 & 0.103 & 0.684 & 0.109 & 0.656 \\
\hline TGC & -0.279 & 0.248 & -0.120 & 0.635 & -0.207 & 0.394 \\
\hline HDL & 0.041 & 0.868 & -0.115 & 0.649 & -0.096 & 0.695 \\
\hline LDL & 0.094 & 0.702 & -0.126 & 0.619 & -0.013 & 0.958 \\
\hline D-HEAS & 0.125 & 0.610 & -0.102 & 0.688 & -0.118 & 0.631 \\
\hline F.Testosterone & 0.158 & 0.519 & -0.114 & 0.652 & 0.023 & 0.926 \\
\hline Insulin & 0.031 & 0.900 & -0.070 & 0.782 & -0.150 & 0.539 \\
\hline Lipoprotein-a & 0.411 & 0.090 & $-0.199^{a}$ & 0.445 & $0.001^{a}$ & 0.998 \\
\hline CRP & 0.310 & 0.197 & $-0.076^{a}$ & 0.763 & $0.086^{a}$ & 0.725 \\
\hline FSH & 0.168 & 0.491 & -0.161 & 0.523 & -0.297 & 0.216 \\
\hline LH & 0.190 & 0.436 & -0.077 & 0.761 & 0.182 & 0.455 \\
\hline TSH & 0.048 & 0.845 & -0.282 & 0.258 & -0.232 & 0.339 \\
\hline HOMA-IR & 0.018 & 0.943 & $-0.049^{a}$ & 0.848 & $-0.150^{a}$ & 0.539 \\
\hline SHBG & 0.019 & 0.937 & $0.013^{a}$ & 0.958 & $0.147^{a}$ & 0.548 \\
\hline $\mathrm{FAl}$ & 0.024 & 0.929 & $0.246^{a}$ & 0.359 & $0.072^{a}$ & 0.790 \\
\hline Systolic BP & 0.367 & 0.218 & -0.220 & 0.470 & 0.095 & 0.757 \\
\hline Diastolic BP & 0.355 & 0.234 & -0.406 & 0.169 & 0.158 & 0.606 \\
\hline
\end{tabular}

a $r=S p e a r m a n ' s$ rho

\section{DISCUSSION}

This study proved the presence of a relationship between affective symptoms and abnormal metabolic parameters inherent to PCOS. We found higher depression and anxiety scores in the control group when compared to women with PCOS. In contrast to our study most of the previous studies reported increased depression rates in women with PCOS.,6${ }^{13}$ One of the most interesting findings of our study was the higher depression scores in the control group, but the lack of correlation between depression scores and metabolic parameters. Although women with PCOS had lower depression scores, their scores were in correlation with the metabolic parameters. In our study depression scores of women with PCOS correlated positively with free testosterone and FAI. Some of the previous studies rejected the association between depression and hirsutism scores or androgen levels, , $, 10,13-15$ and some others remained unclear. ${ }^{16}$ Another study reported higher than normal free testosterone levels in PCOS and found correlation between depression scores and lower testosterone levels. ${ }^{17}$ Increased depression in PCOS was also suggested to be due to the physical appearance created by hirsutism and obesity. 18 We did not check the contribution of Ferriman-Gallwey scores to our results, but we failed to detect a correlation among depression scores and weight or BMI of PCOS patients. We- 
ber et al reported the relationship among increased androgens and depression long ago, ${ }^{19}$ in contrast another study linked lower free testosterone levels to depression..$^{20}$ Even low-dose testosterone treatment was recommended to relieve symptoms of depression. ${ }^{21}$ The relationship between testosterone and mood has not been clearly explained but was suggested to be due to increased sympathetic nerve activity in women with PCOS.22 An alternative explanation was through modulation of neurotransmitters in the central nervous system. ${ }^{23}$

Insulin resistance is a common feature of both obese and lean PCOS and is considered to contribute to hyperandrogenism. Treatments improving insulin sensitivity also reduced hyperandrogenism. ${ }^{22}$ Cinar et al documented the relationship among depression and IR and lipid abnormalities in women with PCOS.6 In our study PCOS patients with depression had statistically significantly lower HDL values but similar to Adali et al. ${ }^{14}$ we did not detect the relationship between depression and impaired glucose tolerance reported in previous studies. ${ }^{13,14}$ PCOS with depression were reported to have higher BMI when compared to PCOS without depression. ${ }^{13,14}$ One study reported higher depression rates in obese PCOS when compared to obese controls. ${ }^{6}$ In our study there was no association between BMI and depression scores.

We did not detect any association between depression scores and inflammatory markers. Benson et al reported higher CRP, IL-6 and white blood cell count in PCOS patients with depression but the effect was found to be related by BMI.23 Increased depression rates were found in the presence of increased IL-6 3,24 and IL-1 $\beta .24,25$ Although our control group had higher anxiety scores, their scores were not correlated to metabolic parameters, except IL-1ß.

Female rats with androgen-induced PCOS showed an anxiety-like behavior, which suggested a role for androgens in the regulation of neurotransmitters. ${ }^{26}$ Supporting the findings of this study, higher anxiety scores in women with PCOS were related to higher free testosterone levels in our study. Previously higher anxiety scores were documented in PCOS with higher HOMA-IR and FAl. ${ }^{28}$ BMI was not associated with anxiety scores, other studies reported diverging findings. ${ }^{11,14,29,30}$ Another interesting finding was the correlation between anxiety scores and Lp-a and HDL. Lp-a is a well-known independent risk factor for cardiovascular diseases and increased levels were reported in women with PCOS previously. ${ }^{31}$ Future studies directed to this marker may provide a further link between anxiety and cardiovascular diseases. Metformin treatment was shown to improve psychological symptoms besides metabolic parameters. ${ }^{29}$ Treatment of metabolic problems of women with PCOS may help them to cope with stress.

The main limitation of our study was the small number of study group. Moreover our control group, although BMI and age matched might not be representative of the normal population as it was composed of hospital staff, students of medicine and nursing. This might be the reason for increased anxiety scores in the control group.

In conclusion, our results suggested a relationship between increased androgens and affective disorders in women with PCOS. A different mechanism may play role in the pathophysiology of affective disorders in women with PCOS. Lp-a may be a marker associated with increased anxiety in cardiovascular diseases. Further studies directed at treatment of affective disorders by treating metabolic problems are warranted.

Current knowledge on the subject: There may be an association between affective disorders and metabolic and hormonal parameters.

What this study adds: Free testosterone levels of women with PCOS were correlated to depression and anxiety scores, the same correlation was not observed in the control group.

\section{REFERENCES}

1. Franks S. Polycystic ovary syndrome. N Engl J Med 1995;333:853-861.

2. Blake GJ, Ridker PM. Inflammatory bio-markers and cardiovascular risk prediction. J Intern Med 2002;252:283-294.

3. Raison CL, Capuron L, Miller AH. Cytokines sing the blues: inflammation and the pathogenesis of depression. Trends Immunol 2006;27:24-31.

4. Raikkonen K, Matthews KA, Kuller LH. Depressive symptoms and stressful life events predict metabolic syndrome among middle-aged women: a comparison of World Health Organization, Adult Treatment Panel III, and International Diabetes Foundation Definitions. Diabetes Care 2007;30:872-877.

5. Skilton MR, Moulin P, Terra JL, Bonnet F. Associations between anxiety, depression, and the metabolic syndrome. Biol Pschiatry 2007;62:1251-1257.

6. Cinar N, Kizilarslanoğlu MC, Harmanci, et al. Depression, anxiety and polycystic ovary syndrome. Hum Reprod 2011;26:3339-3345.

7. The Rotterdam ESHRE/ASRM-Sponsored PCOS Consensus Workshop Group. Revised 2003 consensus on diagnostic criteria and long-term health risks 
related to polycystic ovary syndrome. Fertil Steril 2004;81:19-25.

8. Güngör $\mathrm{O}$, Erden $\mathrm{G}$, Bal C, et al. The comparison of free androgen index and serum free testosterone levels in women with hirsutism or polycystic ovary syndrome. J Clin Exp Invest 2011;2:152-156.

9. Benson S, Janssen OE, Hahn S, et al. Obesity, depression, and chronic low-grade inflammation in women with polycystic ovary syndrome. Brain, Behavior, and Immunity 2008;22:177-184.

10. Keegan A, Liao LM, Boyle M. 'Hirsutism': a psychological analysis. J Health Psychol 2003;8:327-345.

11. Mansson M, Holte J, Landin-Wilhemsen $\mathrm{K}$, et al. Women with polycystic ovary syndrome are often depressed and anxious- a case control study. Psychoneuroendocrinology 2008;33:1132-1138.

12. McCook JG, Reame NE, Thatcher SS. Health-related quality of life issues in women with polycystic ovary syndrome J Obstet Gynecol Neonatal Nurs 2005;34:12-20.

13. Rasgon NL, Rao RC, Hwang S, et al. Depression in women with polycystic ovary syndrome: clinical and biochemical correlates. J Affect Disord 2003;74:299304

14. Adali E, Yildizhan R, Kurdoglu M, et al. The relationship between clinico-biochemical characteristics and psychiatric distress in young women with polycystic ovary syndrome. J Int Med Res 2008;36:1188-1196.

15. Hollinrake E, Abreu A, Maifeld M, et al. Increased risk of depressive symptoms in women with polycystic ovary syndrome. Fertil Steril 2007;87:1369-1372.

16. Weiner CL, Primeau M, Ehrmann DA. Androgens and mood dysfunction in women: comparison of women with polycystic ovary syndrome to healthy controls. Psychosom Med 2004;66:356-362.

17. Jedel E, Gustafson D, Waern M, et al. Sex steroids, insulin sensitivity and sympathetic nerve activity in relation to affective symptoms in women with polycystic ovary syndrome. Psychoneuroendocrinology 2011;36:1470-1479.

18. Dokras A, Clifton S, Futterweit W, et al. Increased risk for abnormal depression scores in women with polycystic ovary syndrome: a systematic review and metaanalysis. Obstet Gynecol 2011;117:145-152.

19. Weber B, Lewicka S, Deuschle et al. Testosterone, androstenedione and dihydrotestosterone concentrations are elevated in female patients with major depression. Psychoneuroendocrinology 2000;25:765771.
20. Morsink LFJ, Vogelzangs N, Nicklas BJ, et al. Health ABCs. Associations between sex steroid hormone levels and depressive symptoms in elderly men and women: results from the Health $\mathrm{ABC}$ study. Psychoneuroendocrinology 2007;32:874-883.

21. Miller KK, Perlis RH, Papakostas GI, et al. Low dose transdermal testosterone augmentation therapy improves depression severity in women. CNS Spectr 2009;14:688-694

22. Moghetti P, Castello R, Negri C, et al. Metformin effects on clinical features, and endocrine and metabolic profiles, and insulin sensitivity in polycystic ovary syndrome: a randomized, double-blind, placebo controlled 6 month trial, followed by open, long-term clinical evaluation. J Clin Endocrinol Metab 2000;85:139146.

23. Sverissidottir YB, Mogren T, Kataoka J, et al. Is polycystic ovary syndrome associated with high sympathetic nerve activity and size at birth? Am J Physiol Endocrinol Metab 2008;294:576-581.

24. Feng Y, Shao R, Weijdegard B, et al. Effects of androgen and leptin on behavioral and cellular responses in female rats. Hormones and Behavior 2011;60:427438.

25. Benson S, Arck PC, Tan S, et al. Disturbed stress responses in women with polycystic ovary syndrome. Psychoneuroendocrinology 2009;34:727-735.

26. Maes M, Scharpe S, Meltzer HY, et al. Relationships between interleukin- 6 activity, acute phase proteins, and function of the hypothalamic-pituitary-adrenal axis in severe depression. Psychiatry Res 1993;49:11-27.

27. Piletz JE, Halaris A, Igbal O, et al. Pro-inflammatory markers in depression: Treatment with venlafaxine. World J Biol Psychiatry 2009;10:313-323.

28. Livadas S, Chaskou S, Kandaraki AA, et al. Anxiety is associated with hormonal and metabolic profile in women with polycystic ovarian syndrome. Clin Endocrinol 2011;75:698-703.

29. Hahn S, Benson S, Elsenbruch S, et al. Metformin treatment of polycystic ovary syndrome improves health-related quality-of-life, emotional distress, and sexuality. Hum Reprod 2006;2:1925-1934.

30. Moran LJ, Misso ML, Wild RA, et al. Impaired glucose tolerance, type 2 diabetes and metabolic syndome in polycystic ovary syndrome: a systematic review and meta-analysis. Hum Reprod 2010;16:347-363 .

31. Berneis K, Rizzo M, Hersberger M, et al. Atherogenic forms of dyslipidemia in women with polycystic ovary syndrome. Int J Clin Pract. 2009;63:56-62. 